\title{
How Protected are Teachers and School Personnel?: Critical Analysis of The Teacher Protection Act (Senate Bill 956)
}

\author{
Abegail P. Simbre ${ }^{1 *}$, Ingrid A. Palad ${ }^{2}$, and Catherine A. Salazar ${ }^{3}$ \\ ${ }^{1,2,3}$ Philippine Normal University, Philippines \\ *e-mail: simbre.ap@pnu.edu.ph
}

\begin{abstract}
The contents of the Senate Bill 956, better known as the Teachers Protection Policy Act was examined and analyzed based on the following themes, namely, support mechanisms for public school teachers and personnel, enhanced protection of public-school teachers and personnel, and training on guidelines and classroom discipline for public school teachers and personnel. According to the Republic Act, 4670 or the Magna Carta for Public School Teachers, the appropriateness of the act was checked to see how much help this bill can provide to the public-school teachers in the Philippines in terms of classroom discipline and classroom management. The bill poses excellent benefits to the public-school teachers. However, the Department of Education must identify which disciplinary acts or strategies are not categorized as child abuse and that there should be centralized policy implementations, seminars, and training to avoid misinterpretations and discipline avoidance among teachers. This paper hopes to contribute to a research-based, logical, and relevant drafting of $H R$ policies and programs to support and protect the teachers as mandated in the Magna Carta for Public School teachers and SB 956. This study employed a qualitative method using resources available online.
\end{abstract}

\section{Keywords:}

Support Mechanism; Teacher Protection; Classroom Management; Student Discipline; Teacher and Personnel Training

\begin{abstract}
ABSTRAK
Isi RUU Senat 956 yang lebih dikenal sebagai Undang-Undang Kebijakan Perlindungan Guru diperiksa dan dianalisis berdasarkan tema-tema berikut, yaitu, mekanisme dukungan untuk guru dan personel sekolah negeri, peningkatan perlindungan guru dan personel sekolah negeri, dan
\end{abstract}


pelatihan tentang pedoman dan disiplin kelas bagi guru dan personel sekolah umum. Kesesuaian Undang-undang tersebut diperiksa menurut Undang-Undang Republik 4670 atau Magna Carta untuk Guru Sekolah Umum untuk melihat seberapa besar bantuan yang dapat diberikan undangundang ini kepada guru sekolah umum di Filipina dalam hal disiplin kelas dan manajemen kelas. RUU tersebut memberikan manfaat besar bagi guru sekolah negeri, tetapi Departemen Pendidikan harus secara jelas mengidentifikasi tindakan atau strategi disiplin mana yang tidak dikategorikan sebagai pelecehan anak dan bahwa harus ada implementasi kebijakan, seminar dan pelatihan yang terpusat untuk menghindari salah tafsir dan penghindaran disiplin di antara para guru. guru. Makalah ini berharap dapat berkontribusi pada penyusunan kebijakan dan program SDM berbasis penelitian, logis, dan relevan untuk mendukung dan melindungi guru sebagaimana diamanatkan dalam Magna Carta untuk guru Sekolah Umum dan di SB 956. Penelitian ini menggunakan metode kualitatif dengan menggunakan sumber daya. tersedia secara online.

\section{Kata kunci:}

Mekanisme Pendukung; Perlindungan Guru; Pengelolaan Kelas; Disiplin Siswa; Pelatihan Guru dan Personel

\section{Introduction}

Teachers play a vital role in our educational system. Their efforts and sacrifices to educate the youth cannot be underestimated nor be ignored because they hold the great duty of nurturing and equipping their students to become morally, intellectually, physically, socially better citizens of the country in the future. They are professional educators in carrying out teaching and learning activities inside and outside schools to discipline students to become responsible, honest, and lawabiding people (Suharyanta, 2020). They are also even demanded to participate in instructional leadership as distributed leadership nowadays found it effective to promote collaborative and democratic approaches in teaching and learning towards school improvement (Shava, Heystek, \& Chasara 2021). Any support from school leaders would greatly help teachers in this area (Aldrup et al., 2018). More than these, teachers are also responsible for developing themselves as role models of their inculcate values while facilitating learning (Amin \& Ahmed, 2021).

In the Philippines, teachers in the public school system always work extra miles to better provide their services to the students (Baluyos, Rivera, \& Baluyos, 2019). They usually handle an extensive workload which consists of too many clerical tasks, working beyond school hours to help in school programs or to conduct remedial lessons to his/her students, not to mention working on other varied tasks until the wee hours at night to prepare their lessons for the next day (Harmsen et al., 2018). Their tasks are not limited to teaching alone but also with other community programs that overlap with their time outside of schools, reducing their time for the family and even their rest. 
One of the most challenging tasks of teachers is classroom management and discipline. Nemenzo (2018) found out that among the problems encountered by teachers in the teachinglearning process are initiated discipline of the students and classroom management which were both identified as "serious problems," resulting in a call for action to minimize the problem. Most of the time, teachers have been conscientious in disciplining their students that they sometimes tend to overlook their students' misbehavior in class for fear that they will violate the Child Protection Act (Simbre \& Ancho, 2019; Urai Musa \& Ariyanti, 2020). As mentioned by Kasmawati (2018), the existence of the Child Protection Act psychologically affects teachers to punish the students who commit the offense.

Additionally, there are many scandalous cases involving public school teachers being accused of child abuse in the performance of their duties, specifically in imposing classroom discipline. In research, the misconduct of classroom teachers was magnified among the court cases and news articles on an examination of malpractice in the education context where more teachers are charged with abuses and minor offenses (Calderon \& Ancho, 2018).

Given how powerful and destructive social media can be, teachers are very hesitant to discipline students nowadays (Simbre \& Ancho, 2019) because they can quickly and helplessly be subjects of bashing on social media, TV, and radio. Some social media influencers ride on these cases and make them viral on social media, leading to teachers' downfall. An example of this case was when a parent/guardian complained about a teacher who allegedly embarrassed and physically abused a child on a popular TV and Youtube show. The host and the involved guardians litigated the teacher live on TV leading the teacher to apologize. The guardian insisted that the teacher's license be revoked, while the parents exclaimed that they wanted the teacher to just rest by resigning from service. The host, Raffy Tulfo, suggested options (to get her license to be revoked by the PRC or to resign and rest). Later on, the publicly humiliated teacher chose the latter to resign from service (Tulfo, 2019).

For teachers to do their roles more effectively and efficiently, they need to be empowered and protected (Petrusheva, 2020). Considering their sacrifices for the country and the people, it is just proper and lawful to protect and empower them. With these premises, the researchers were motivated to analyze the contents of the Teacher Protection Act critically and to discuss further and analyze what the strengths and weaknesses of Senate Bill 956 are and what themes emerged from the analysis of the contents of the Teachers' Protection Policy Act (TPA) and how the act supports the Republic Act 4670 (Magna Carta for Public School Teachers). The rationale is to establish and see the balance of both the rights and responsibilities of learners and educators and contribute to the enhanced support, protection, and training of public school teachers and personnel.

On the aspects of child abuse, Senate Bill No. 956 is intended to clarify the guidelines on classroom discipline not deemed child abuse. The World Health Organization (WHO) and the International Society for Child Abuse and Neglect identified three major components to a 
systematic approach to preventing child maltreatment. These components are mechanisms in investigating cases, preventing child maltreatment at all levels, and supporting the maltreated children and their families. The education sector is also focused on RA 7610 (Special Protection of Children Against Abuse, Exploitation and Discrimination Act), RA 9262 (AntiViolence Against Women and their Children Act of 2004), and DepEd Order No. 40, series 2012 (DepEd's Child Protection Policy). Bayucca (2020) also found out in her study that teachers are knowledgeable about DepEd Child Protection Policy and recommended its implementation of regular monitoring at the school level to ensure positive and non-violent discipline in classroom management. However, none was made to protect the teachers. This made teachers hesitant to discipline students due to different recent teachers' alleged classroom abuse and malpractice when imposing disciplinary measures on students.

Teachers were human, too, with due rights for necessary protection in the performance of their duties. They can also be a target of students' and parents' bullies. It can be in the form of misbehavior, cyberbullying, insulting words, spreading false and malicious rumors, and worst, students can harm them physically and mentally. The provision of Commonwealth Act 578 was duly amended by Article 512 of the Revised Penal Code of the Philippines; teachers became persons in authority. This gave the teachers protection, dignity, and respect due to them. Furthermore, such protection, dignity, and respect are permanently attached to the performance of their duties (Bauzon, 2006).

However, due to the child protection act, teachers were hesitant to exercise their rights that is why it is deemed necessary to review the content of Senate Bill 956, also known as teacher's protection Policy Act, to understand further its content for the protection and welfare of the teachers in general. Tanjung and Darwin (2019) found out that there is a need to review the DepEd Orders and policies regarding the uniformity and consistency of the school policy that applies equally to every member of the educational institution, be they are school administrators, classroom teachers, and office personnel.

Occurrences of efforts among Philippine legislators implied that it is about time to review existing laws and promulgate laws to strengthen teachers' rights and protection further. In an online article on the Philippine Information Agency website dated September 18, 2020, Senator Win Gatchalian, Chairman of the Senate Committee on Basic Education, Arts and Culture, is seeking a comprehensive and critical review of the 50-year-old Magna Carta for Public School Teachers (Republic Act No. 4670) in order to advance the working and living conditions of public-school teachers through filing the Senate Resolution No. 552. According to Gatchalian, it is timely that the government's protection to public school teachers be assessed and identify ways how public-school teachers' welfare be protected.

Among many bills which aim to protect teachers further, ACT Teachers Party-List Representative Antonio L. Tinio, through House Bill No. 5735 (Student Discipline and Teacher Protection Act), reiterating that as the law protects the rights of every child, it is also necessary that 
teachers must be protected by law as well. The bill also suggests that there is a need to mandate implementation of a student manual stipulating correct protocol in handling the disciplinary cases based on the disciplinary rules and procedures that DepEd will release to avoid teachers being charged with the violation of RA 7610 (Special Protection of Children Against Abuse, Exploitation and Discrimination Act) and other laws that protect rights and welfare of the children.

Additionally, Senator Grace Poe filed Senate Bill No. 1189 (An Act Institutionalizing Support Mechanism for Teachers and Personnel in the Public School System) seeking for necessary protection to public school teachers and personnel from accusations of child abuse in matters of student discipline and mandating the Department of Education to the issuance of manual and training on child behavior and psychology, effective classroom management and appropriate discipline techniques.

They deem that passing this bill will empower the teachers as they fulfill their duties and create a more conducive learning climate for students as we continue to pursue the excellent quality of education (Sadik, 2018). Given the above premises, the authors were motivated to review the strengths and weaknesses of the Teacher Protection Act (Senate Bill 956) and critically analyze it with consideration to Republic Act 4670 Magna Carta for Public School Teachers. This act will somehow give teachers some freedom to better correct their students' behavior. Institutionalizing this support will better set the boundaries of the Teachers' Protection Act, Republic Act 7610, or the Child Protection Act as any form of discipline they employ may put them in a wrong position against the latter bill. Hence, this bill will provide a better and more effective discipline structure to employ as they continue to hone their students to become better people.

The following are the research questions for this study:

1) What are the strengths and weaknesses of Senate Bill 956 (Teacher Protection Policy Act) in terms of:

a. support mechanism for public school teachers and personnel,

b. enhanced protection for public school teachers and personnel, and

c. training on guidelines and classroom discipline for public school teachers and personnel?

2) How does Senate Bill 956 (Teacher Protection Policy Act) support the Republic Act 4670 Magna Carta for Public School Teachers?

\section{Methods}

This study employed qualitative research through content analysis of documents and data available online. According to Maxwell (2016), qualitative research relies on various types of 
understanding validity through describing, explaining, and interpreting a phenomenon. The primary documents used for this research study were the Senate Bill 956 (Act Institutionalizing Support Mechanisms and Protection for Public School Teachers and Personnel in Matters of Student Discipline for Classroom Management) and Magna Carta for Public school Teachers (RA 4670). The contents of Senate Bill 956 were carefully analyzed in terms of its strengths and weaknesses through identifying emerging themes from the different sections of the bill. Its appropriateness was also checked using the Magna Carta for Public school Teachers (RA 4670) along with the Child Protection Act. This study depended on documentary data; hence, there were no potential ethical risks against any teachers or students. Data extracted from these were treated objectively and fairly.

\section{Results and Discussion}

This section presents the results and discussion as a critical analysis of Senate Bill 956 (Teacher Protection Act) based on the emerging themes. These themes include the support mechanism to public school teachers and personnel, enhanced public-school teachers and personnel protection, and training on guidelines and classroom discipline for public school teachers and personnel.

Table 1. Key Points of the Act: Salient Points of the Senate Bill 956 (Teacher Protection Policy Act

\begin{tabular}{|c|c|}
\hline Concepts & Key Points \\
\hline \multirow[t]{5}{*}{$\begin{array}{l}\text { Support Mechanism for } \\
\text { Public School Teachers } \\
\text { and Personnel }\end{array}$} & $\begin{array}{l}\text { Provision of mechanisms necessary to capacitate teachers } \\
\text { on child behavior and psychology, classroom management } \\
\text { techniques, positive discipline, etc. (Sec 10) }\end{array}$ \\
\hline & $\begin{array}{l}\text { Promotion and improvement of working conditions } \\
\text { (physical and emotional environments) conducive to } \\
\text { learning and teaching of public-school teachers and students } \\
\text { (Sec 2) }\end{array}$ \\
\hline & $\begin{array}{l}\text { Meaningful involvement in the formulation of guidelines by } \\
\text { students, parents, teachers, school staff, and community } \\
\text { (Sec 5) }\end{array}$ \\
\hline & $\begin{array}{l}\text { Providing teachers and school personnel legal assistance } \\
\text { and representation ( } \operatorname{Sec} 11)\end{array}$ \\
\hline & $\begin{array}{l}\text { Having a secure number of items for guidance counselors to } \\
\text { act as support personnel in matters of student discipline } \\
(\mathrm{Sec} 9)\end{array}$ \\
\hline $\begin{array}{l}\text { Enhanced Protection of } \\
\text { Public-School Teachers } \\
\text { and Personnel }\end{array}$ & $\begin{array}{l}\text { Provision of legal assistance and representation for cases } \\
\text { related to student discipline and classroom management } \\
\text { (Sec 11) }\end{array}$ \\
\hline
\end{tabular}


Acts according to the disciplinary rules and procedures shall not be tagged as child abuse or exploitation ( $\mathrm{Sec} 4)$

Ample representation by the accredited or registered union (Sec 11)

No publicity of a case, personal information that may reasonably identify them are to be disclosed during its pendency of proceedings (Sec 12)

Training on Guideline and Classroom Discipline for Public School Teachers and Personnel
Inclusion of Conduct of periodic seminars and formulation of primers and other explanatory materials (Sec 10)

Guidelines on handling of cases shall be issued for the media (Sec 12)

Establish and maintain support systems, including training on classroom management and child discipline and legal assistance for teachers and school staff ( $\mathrm{Sec} 2)$

Issuance of guidelines on the implementation of Teacher Protection (a) rights and responsibilities of teachers in classroom management and discipline, b) permissible, appropriate, and effective responses and interventions, c) clear description of disciplinary procedures and designation of authorities to handle cases) (Sec 3)

Provision of explanations, training, and workshops to familiarize students and families with the guidelines to explain the expectations, preventive, favorable responses, and interventions ( $\mathrm{Sec} 6)$

Giving of annual instructions related to specific contents in the guideline ( $\mathrm{Sec} 7$ )

Providing appropriate pre-service and in-service training on child behavior and psychology, classroom management techniques, positive discipline and other related fields, and scopes of duties and responsibilities ( $\mathrm{Sec} 8$ ) 
Table 2. Key Points of the Act: Strengths and Weaknesses of Senate Bill 956 (Teacher Protection Policy Act

\begin{tabular}{|c|c|c|}
\hline Concepts/Themes & Strengths & Weaknesses \\
\hline \multirow[t]{4}{*}{$\begin{array}{lr}\text { 1. Support Mechanism } \\
\text { for Public } & \text { School } \\
\text { Teachers } & \text { and } \\
\text { Personnel } & \end{array}$} & $\begin{array}{l}\text { Capacitating teachers on } \\
\text { child behavior and } \\
\text { psychology, classroom } \\
\text { technique }\end{array}$ & $\begin{array}{l}\text { Teachers' awareness of } \\
\text { child protection policy } \\
\text { needs integration of non- } \\
\text { violent discipline, } \\
\text { anger/stress management, } \\
\text { and gender sensitivity. } \\
\text { (Bayuca, 2020) }\end{array}$ \\
\hline & & $\begin{array}{l}\text { Incidences of child } \\
\text { protection issues and failure } \\
\text { on its early detection despite } \\
\text { child protection policy } \\
\text { awareness and school } \\
\text { implementation. (Cervancia } \\
\text { et al., 2019) }\end{array}$ \\
\hline & $\begin{array}{l}\text { To detail teachers' rights and } \\
\text { responsibilities concerning } \\
\text { student discipline in } \\
\text { classroom management }\end{array}$ & $\begin{array}{l}\text { Child protection policy } \\
\text { makes teachers } \\
\text { apprehensive about } \\
\text { punishing classroom } \\
\text { discipline violations. } \\
\text { (Kasmawati, 2018) }\end{array}$ \\
\hline & $\begin{array}{l}\text { To have guidance counselors } \\
\text { to assist in student discipline }\end{array}$ & $\begin{array}{l}\text { there are not many guidance } \\
\text { counselors, so school's just } \\
\text { assign a guidance teacher to } \\
\text { man the position } \\
\text { (Magsambol \& Chi, 2020, } \\
\text { Pererva et al., 2018) }\end{array}$ \\
\hline \multirow[t]{2}{*}{$\begin{array}{l}\text { 2.Enhanced protection of } \\
\text { Public-School Teachers }\end{array}$} & $\begin{array}{l}\text { Provision of legal assistance } \\
\text { and representation for cases } \\
\text { related to student discipline } \\
\text { and classroom management } \\
\text { (Sec 11) }\end{array}$ & $\begin{array}{l}\text { Not many teachers are } \\
\text { members of unions } \\
\text { (Medenilla, 2018; PSA, } \\
\text { 2019; ITUC, 2019) }\end{array}$ \\
\hline & $\begin{array}{l}\text { Instituting guidelines on } \\
\text { permissible, clear, and } \\
\text { specific interventions to } \\
\text { address students' violations } \\
\text { and execute disciplinary } \\
\text { procedures (Sec 3) }\end{array}$ & $\begin{array}{l}\text { Existence of inequitable } \\
\text { compliance, poorly } \\
\text { communicated and limited } \\
\text { capacity to handle student } \\
\text { discipline reforms } \\
\text { (Anderson, 2018) }\end{array}$ \\
\hline
\end{tabular}


Students who were subject

to discipline incidents tend

to have a worse perception

of school climate. (Huang \&

Anyon, 2020)

3. Training on Guideline and Classroom Discipline for Public School Teachers and Personnel
Giving seminars and training on child behavior and

psychology classroom management techniques (embedded in all sections)
The budget on the conduct of training and seminars (Gonong, 2018)

Systemic corruption (Rothstein, 2018; Trines, 2017), nepotism, bribery may threaten the delivery and dissemination of information.

alignment of seminars to the needs of the educational system (DepEd, 2020)

Table 3. Sections of the Act and Concept Focus

\begin{tabular}{|c|c|}
\hline Concepts & Section of The Act \\
\hline $\begin{array}{lr}\text { Support } & \text { Mechanism } \\
\text { for Public } & \text { School } \\
\text { Teachers } & \text { and } \\
\text { Personnel } & \end{array}$ & $\begin{array}{l}\text { Sec 3. Guidelines on the Implementation of Teacher Protection } \\
\text { Sec 5. Consultation of Involved Sectors in the Drafting of } \\
\text { Guidelines } \\
\text { Sec 9. Support Personnel }\end{array}$ \\
\hline $\begin{array}{l}\text { Enhanced } \text { Protection } \\
\text { of } \quad \text { Public-School } \\
\text { Teachers } \quad \text { and } \\
\text { Personnel }\end{array}$ & $\begin{array}{l}\text { Sec 4. Acts according to the Guidelines Not Deemed as Child } \\
\text { Abuse } \\
\text { Sec 10. Other Support Mechanisms for Student Discipline and } \\
\text { Classroom Management } \\
\text { Sec 11. Protection of Teachers and School Personnel in } \\
\text { Charges Related to Student Discipline and Classroom } \\
\text { Management } \\
\text { Sec 12. Confidentiality of Identity of Parties and Proceedings } \\
\text { under this Act }\end{array}$ \\
\hline $\begin{array}{l}\text { Training on Guideline } \\
\text { and Classroom } \\
\text { Discipline for Public } \\
\text { School Teachers and } \\
\text { Personnel }\end{array}$ & $\begin{array}{l}\text { Sec 6. Information Dissemination of the Guidelines } \\
\text { Sec 7. Training of Teachers and School Personnel of the } \\
\text { Guidelines } \\
\text { Sec 8. Professional Development Relating to Student } \\
\text { Discipline and Classroom Management }\end{array}$ \\
\hline
\end{tabular}




\subsection{Support Mechanism for Public School Teachers and Personnel}

Training and recruiting qualified teachers, wherever they are global, is essential for the education system's success. This is because pre-service and in-service teacher training is among the factors affecting school success and providing development of the education system (Sahin \& Akinci, 2020 cited in Cheng, 2016; Dietrich \& Krache, 2017; Livingston, 2016). (Section 8) of Senate Bill 956 reiterates that the Department of Education shall provide teachers the appropriate pre-service and in-service training on child behavior and psychology, classroom management techniques, positive discipline, and other related fields, as well as on the guidelines and the scope of their duties and responsibilities concerning student discipline and classroom management. This bill supports RA 4670, otherwise known as the Magna Carta for Public School Teachers, which focused on promoting and improving the social and economic status of public-school teachers, their living conditions, and their employment and career prospects. Although training on child behavior and classroom management was not mentioned in RA 4670, Senate Bill 956 says it provides a wide array of support for teachers in their professional development relating to student discipline and classroom management.

Teaching is a profession that requires the ability to be responsive to new demands and changing needs that must be provided with timely and relevant training. Moreover, classroom management and student discipline are areas that teachers must train on. One aspect of effective classroom management is effectively handling student misbehavior. Managing misbehavior is a chronic problem for teachers (Eggen \& Kauchak, 2004 cited in Korb, Musa, \& Bonat 2016, Bordios, 2018). Teachers need various strategies for managing student behavior and understanding which strategies are generally more meaningful than others. A sophisticated form of training is needed to help teachers learn and refine their skills in handling child behavior and psychology, classroom management techniques, and positive discipline.

Tuncel and Cobanoglu (2018) pointed out that individuals should develop themselves in line with the needs and requirements of the institutions they work in as soon as they start to perform occupation professionally. The requirement of this development roots in many factors such as having the profession's qualifications, fulfilling the deficiencies, adapting to the working place, having better professional performance, and advancing in the career. Teachers who are skills at classroom management may appear to outsiders as "naturals," operating their classroom with calmness and precision that disguise the consistent cycle of reflection and adjustment they use to manage their students and the learning environment Schafer and Barker (2018). With all this in mind, Senate Bill No. 956 needs to be passed as a law to improve the teacher's capacity to handle classroom management and positive discipline from time to time to meet the demands of the teachers' changing work environment student behavior and discipline. Classroom management is organizing in-class activities and guiding behaviors (Basar, 2009 cited in Uz \& Bayraktar, 2019). A teacher should have enough knowledge and skills related to classroom management to determine, remove and improve undesirable student behaviors (Yuksel,2013; Ozcan, 2012, Demirtas; 2011 cited in Uz \& Bayraktar, 2019). According to UNESCO (2015), as the working environment plays 
an essential role in the quality of teaching in several countries like Australia, Bangladesh, Barbados, Ghana, Iraq, and Sweden have adopted measures like inverting in material resources and teaching aids, addressing the issue of classroom overcrowding and increasing human resources in the classroom. Meanwhile, in the Philippines, public school teachers are chronologically overworked (Esguerra, 2018 cited in David, Albert, \& Vizmanos, 2019). The workload of public-school teachers is not limited to teaching but also other non-teaching tasks.

According to David, Albert, and Vizmanos, (2019), several administrative or student support roles are assigned to teachers. These include paperwork on seminars and training. They are tasked to attend additional designations in line with student's guidance, budget, disaster response, and health. Teachers are likewise expected to participate in implementing various government programs, such as mass immunizations, community mapping, conditional cash transfer, deworming, feeding population census, anti-drug, and election. Republic Act 4670 or the Magna Carta for Public School Teachers reiterated in Department of Education Memorandum Order No. 291 s. 2008 and remunerated in Department Order No. 16 s 2009 that teachers should engage in actual teaching/classroom instruction for six (6) hours and the remaining two (2) hours to prepare and correct exercises and other work incidental to his regular teaching duties.

The study conducted by Bongco and Ancho (2019), Exploring Filipino Teachers' Professional Workload, revealed that Teachers indicated that they find it challenging to complete mandated tasks within an eight-hour workday. All participants unanimously believed that the said time is not enough to accomplish everything that must be done. This compels teachers to take home some of the work that has to be completed, sometimes working in the evenings. Teachers doing administrative work-a a situations hidden from the view of the usual metrics- can erode teaching quality (David et al. 2019).

House Representative France Castro (cited in Quismorio, 2020) pointed out that the administration of quality education is impossible without teaching assistants, registrars, clerks, school doctors, nurses, psychologists, guidance counselors, librarians, and the rest of the professional administrative, technical and general working in the education sector. She also mentioned that the lack of education support personnel forces teachers to fulfill nurses, guidance counselors, maintenance staff, security guards, clerks, and many others. According to UNESCO (2015), To ensure good quality teaching and learning, teachers should be well supported, motivated, and trained. Section 9 of Senate Bill 956 urges the Department of Budget and Management to ensure that there are enough guidance counselors who will serve as support personnel to teachers and school administrators in student discipline matters. This bill should be passed into law simply because it would, in any form or another can help lessen if not remove the administrative functions that the public-school teachers weigh in for several times of their lives just to do or accomplish the task assigned to them. 


\subsection{Enhanced Protection of Public-School Teachers and Personnel}

Senate Bill 956, as the subject of this research, reflects the need for the protection of public school teachers and personnel in matters of student discipline for the classroom. Three sections in the bill focused on the theme of the protection of public school teachers and personnel: (Section 3) Guidelines on the Implementation of Teacher Protection, (Section 11) Protection for Teachers and School Personnel in Charges Related to Student Discipline and Classroom Management, and (Section 12) Confidentiality of Identity of Parties and Proceedings under this Act.

Section 3 of the Senate Bill 956, entitled Guidelines on the Implementation of Teacher Protection, states that the Department of Education must issue guidelines on implementing the act. About discipline and classroom management also stipulated that the guidelines must include the rights and duties of teachers, permissible and appropriate interventions to address students' violations, and straightforward disciplinary procedure, and the explicit designation of the authorities who will implement the procedure of investigation and responses. Generally, every organization needs well-written and effectively communicated guidelines as it states the standards for implementing a specific policy. Guidelines help an organization avoid inconsistencies, protect the company from legal actions and serve as a learning tool to the members of an organization.

In terms of classroom management, Buonomo, Fatigante and Fiorilli (2017) wrote that professional activation of teachers' responsibilities can lead to a perfect learning environment and that their efficient classroom management provides students with opportunities to express themselves and make practical use of their learning activities inside the classroom. Article VIII, Section 2 of the Code of Ethics for Professional Teachers emphasized that it is the teachers' responsibility to promote with justice and impartiality the learners' interest and welfare as the first and foremost concern.

As student discipline is always part of classroom management, a study on the publ,ic-school teachers' point of view on student discipline in the classroom reveals, based on the lived experiences of the public school teachers, the six issues experienced by teachers in classroom discipline (García-Carmona et al., 2018). These issues are harassment and intimidation, student defiance and disobedience, teachers' risk of litigation, parental assent. The favorable learning environment and appreciation (Virtudazo \& Guhao, 2020). This reflects that the present generation of students are very much enjoying their freedom as they were protected by different laws such as RA 7610 (Special Protection of Children Against Abuse, Exploitation and Discrimination Act), RA 9262 (AntiViolence Against Women and their Children Act of 2004) and DepEd Order No. 40, series 2012 (DepEd's Child Protection Policy). This made teachers and school personnel hesitant to discipline students due to different recent teachers' alleged classroom abuse and malpractice when imposing disciplinary measures on students.

Aside from being oriented to the laws that protect the rights of every student, teachers and school personnel also need to be well-guided by guidelines that protect them, like what Section 3 of 
the Senate Bill 956 stipulated. They must know which responses and interventions are permissible when a student violates the school's policy or the policy imposed in a classroom. This supports Section 12 of RA 4670 (The Magna Carta for Public School Teachers), which states that academic freedom for teachers means freedom to execute their duties, especially in terms of teaching and classroom methods. The freedom of the teachers and the students to pursue knowledge and research without unreasonable interference or restrictions from the law, institutional regulations, or public pressure. Estrada (2019) explains academic freedom from an academician's point of view as a teacher's freedom to adapt their teaching methods and techniques free from unreasonable limitations. Teachers and school personnel, as persons responsible for molding the character of the students when they are on school premises, must be given a more precise direction on how they will perform their duties that they consider professionally appropriate and at the same time not violating the rights of the students.

Section 3 of Senate Bill 956 is also supported by Chapter 2 of The Family Codes of the Philippines. Article 218 provides that school administrators and teachers engaged in the supervision and instruction or custody shall have special parental authority and responsibility for a minor learner, whether inside and outside the school premises. This clarifies that teachers and other school personnel have a substitute and special authority over every child in their custody; thus, parents must also allow teachers and school personnel to discipline their children in ways that are deemed appropriate.

Article 220 (3) of the Family Codes of the Philippines stipulates that providing minors with moral and spiritual guidance is among the rights and duties of those exercising parental authority. Students under the control and influence of the school and within its premises are subject to the discipline and responsibility of the school authorities and personnel - that disciplinary measures being imposed by the teachers and school personnel in order to impose these positive virtues must not be viewed as violence and abuse.

However, Article 219 of the Family Codes of the Philippines also provides that parents, guardians, or those exercising parental authority over a minor shall be primarily liable for the damages caused by the child. These are also supported by other laws protecting the rights of the children and the learners. The given premises: therefore, emphasized the point of Section 3 of Senate Bill 956 that there is a need to detail the right and responsibilities of a teacher concerning student discipline; the permissible, appropriate, and effective responses and interventions to address students' violations; and the disciplinary procedure as well as the competent authorities to implement the guidelines. However, in the implementation of the reform on guidelines regarding interventions and procedures on students' discipline, the school's administration and personnel must consider possible issues that may arise. According to Anderson (2018), there is an inequitable implementation of reforms on students' discipline and poor communication of guidelines, and limited school capacity to handle discipline issues. Huang and Anyon (2020) also found a significant relationship between students' involvement in discipline incidents and their negative 
attitudes towards school and the school climate, implying that school personnel must be more cautious in executing disciplinary procedures.

Moving to the second section of the Senate Bill 956 focusing on the right of teachers and other school personnel for protection, particularly those involved on charges related to school discipline in classroom management. Section 11 of the said bill demands DepEd to extend legal protection and representation in case teachers and other school personnel get involved in criminal and administrative charges of child abuse in the performance of their duties in student discipline and classroom management (Swanzen, 2018).

In the 1987 Constitution of the Republic of the Philippines, Article III, Section 1 reads that everybody has the right to life, liberty, property, and equal protection of the law. As applied to teachers, this right is stipulated explicitly in the Magna Carta for Public School Teachers, Section 9, on how an administrative charge against a teacher can be heard. The law provides that there must be a committee to hear administrative charges against teachers initially. The committee must be composed of the concerned school division superintendent or a representative who is at least a division supervisor as a chairman, representative of the local/regional/national teachers' organization, and a supervisor of the division. This committee shall submit findings and recommendations within thirty days after the hearing to the Director of Public Schools.

Section 9 of Magna Carta for Public School Teachers was also the reference law of The Revised Rules of Procedure of the Department of Education in Administrative Cases (DepEd Order No. 49, s. 2006) on its Section 21 specifying the creation of a Formal Investigation Committee of the Disciplining Authority within five days from the receipt of respondent's answer. Also, the DepEd Grievance Machinery states that the agency's head shall ensure equal opportunities for men and women to be represented in the committee.

Attempts to pass a law that will further promote protection to teachers emphasized the urgent necessity that it is about time for the lawmakers to balance the rights that will protect and promote the welfare of both the children, teachers, and other school personnel.

Furthermore, another section of Senate Bill 956 (Teacher Protection Act) provides another right to protection of teachers and other school personnel through Section 12: Confidentiality of Identity of Parties and Proceedings under this Act, providing that no person, in private or public parties, shall publicize or disclose the case and the identity of the complainants and respondents during the pendency of the proceedings.

The section also ordered that DepEd issue its guidelines for the media about handling cases concerning the confidentiality and privacy of teachers and school personnel being charged or accused with administrative and criminal cases. This includes the confidentiality of the proceedings and the identity of the parties involved. Section 10 of the Magna Carta for Public School Teachers postulated that there should be no discrimination among teachers in the entrance of the teaching profession and during its exercise and termination of the service. 
In the legal context, it is mandated that a person, unless proven guilty in the court of law, shall remain innocent. Therefore, to avoid the adverse effects when a teacher or school personnel was allegedly charged with administrative and criminal cases, the confidentiality of the case must be observed. As also stated on the basic policy of DepEd Grievance Machinery, involved parties must be assured of freedom from coercion, discrimination, reprisal, and biases.

Rights have corresponding responsibilities. The truth of this cliche as applied to the fight for the protection of teachers and other school personnel on matters concerning discipline in classroom management requires active participation and labor not only on the part of the administration, the teaching, and the non-teaching personnel but also to the those who implement the law in performing their duties - envisioning a law that instructed a stronger defense on the part of the teacher and school personnel which demands a workable system that remedies the specific cause of problem concerning student discipline and classroom management, promotion of a whole and desirable school environment, and training regarding child behavior psychology, among others.

\subsection{Training on Guideline and Classroom Discipline for Public School Teachers and Personnel}

One of the most critical challenges in educating our students these days is dealing with classroom management. Teachers are now put in minimal ways to manage classroom discipline. Teachers have confirmed this in a study conducted by Simbre \& Ancho (2019), where teachers claimed that the most challenging thing teachers must deal with at work is pupil discipline. In Section 4 of the SB 956, it stated that any act committed by a teacher or school staff under the disciplinary rules and procedures issued by the DepEd should not be deemed as child abuse, cruelty, or exploitation as defined in RA 7610 or the Special Protection of Children Against Abuse, Exploitation, and Discrimination Act.

However, it is stated in DepEd Order NO. 40, s. 2012, that child abuse is not limited to physical and verbal abuse but encompasses anything that may affect the pupils psychologically. The term "psychological" is too broad to any boundaries, and the risks are too high to any teacher in the service. Let us say teachers do not say anything but just give the child a blank and quiet stare. No debasing words, no physical contact, just a stare may be deemed to be psychologically disturbing. Pupils may claim that they are greatly bothered by anything the teacher may say and do, so teachers may be summoned by any little thing she may say and do, intentionally or not, for anything that the child claims to be psychologically disturbing. The problem with this part is that there are no clear boundaries as to where the limits are. Teachers can be summoned and accused by people without even hearing their sides of the story. As Virtudazo and Guhao (2020) remarked in their study, Schools should have a Teacher Protection Policy considering what these students can freely do to the teachers because of the Deped's Child Protection Policy law that protects them.

As per the Republic Act No. 4670 or the Magna Carta for Public School Teachers states on Section 8, Safeguards in Disciplinary Procedure, "Every teacher shall enjoy equitable safeguards at each stage of any disciplinary procedure and shall have: a) the right to be informed, in writing, of 
the charges; b) the right to full access to the evidence in the case; c) the right to defend himself and be defended by a representative of his choice and/or by his organization, adequate time being given to the teacher for the preparation of his defense; and d) the right to appeal to designated authorities." Unfortunately, none of these was given to the teacher. The people who watched the show raised their concerns about how the host handled the situation. She resigned not because she was guilty but because of the moral damages it caused the teacher and her family. The netizens' hearts went out for her, but the damage had already been done.

If the bill were passed into law, proper proceedings would be expected. Instead of this, school leaders are expected to uphold the child's rights and protect the people who help raise the child at school. With the help of this bill and the Magna Carta for Public School Teachers, teachers would be able to protect their rights as a teacher, human and a Filipino citizen.

However, to fully protect the teacher from possible hazards in classroom discipline, the Department of Education must draw clear lines on the disciplinary rules and procedures. Policies and programs should be developed to help teachers discipline their students. After all, this should not be treated as a classroom problem but a community concern because the child should be first taught discipline at home and in the community. Many studies have shown that parenting programs in schools may improve parental involvement and lessen disciplinary issues. However, unfortunately, there is a scarcity of policies to address this (Simbre \& Ancho, 2019). In their study, their recommendations include the following: developing a behavior management plan or a development training plan which includes all the proven behavioral techniques and can be adopted by schools to help teachers with discipline issues, and consistent conduct of parenting seminars to help parents and teachers with student discipline. It would be better if the whole bureau would uniformly conduct these for consistency in implementation and a better understanding of teachers and school staff. These could greatly help teachers handle the misbehaviors of their pupils.

In Section 5 of SB 956, it states that stakeholders, namely, students, parents, teachers, other school personnel, and the community, represented by their organizations, as well as professionals in child behavior and social work, shall each have meaningful involvement in the formulation of these guidelines so that they all could agree on the expectations and disciplinary preventions, responses, and interventions they all could use at school.

Deped promotes positive discipline, but the bureau still needs to work on teacher training on more ways to handle challenging classroom behaviors. Teachers are also humans, they feel emotions, and to some extent, their patience could go up to the brims and lose it. A simple glare could put them at risk, and yelling could be worse. Ignoring the act of misbehavior is also not a good option for teachers to avoid disciplinary violations. To simply put, being strict in the slightest sense may not help anymore.

Each class is different from the other, and so are children from families of different backgrounds. Some of them come from homes where cursing is strictly prohibited, but to some, it is 
just a standard language they hear and say with their family. Each family is unique too. Others are too distant. Could hardly see them even on PTA meetings, but some are overly visible that they tend to hover over their kids at school. We cannot underestimate that teachers try their best to deal with each of these differences among their students and their parents, but their work is not limited to just teaching alone. They are mostly swamped with their students' test papers and other clerical jobs. Not one in the service just teaches the whole day. Everyone has their other tasks to do and meetings/ seminars to attend.

In this sense, strengthening the parent-teacher relationship has a significant role in student discipline. Canter (2010) stated a need to develop a responsible curriculum because if students do not learn how to behave responsibly and non-disruptive, their academic performance will also suffer. In his book, he provided sample curriculums that schools may adopt. DepEd should also provide similar training to their teachers. Carter also mentioned two critical steps to increase teachers' success in this endeavor: the Real-Time Classroom Coaching Model that enables mentors and coaches to assist teachers with their behavior management skills and establish a school-wide assertive discipline program model to support teachers' efforts.

Moreover, Monteiro and Lourenco (2018) suggested a structural model on positive discipline, which includes the following points: students' commitment, students' learning motivation, and students' self-control, and among these three, students' commitment can be a solution to positive discipline. Hence Deped adapts this model and develops a program based on Filipino values and culture. They also added that making students aware of their behaviors will permanently release teachers from their administrative role; hence a behavioral curriculum and behavioral management plan aside from the guidelines should be prepared to protect the teachers adequately. There should be a massive involvement of stakeholders in designing plans, programs, and policies. Proven by many researchers and experts in the past, successful initiatives happen when there is public, private, and community involvement. It is essential to acknowledge the involvement of the private and community sector and then analyze the constraints in establishing partnerships on a larger scale. In addition to that, there is a need to revisit policies to develop to protect teachers from legal charges. Teachers have become apathetic when it comes to classroom discipline because there is nothing they could depend on when they discipline their students. They have to be armed with legal knowledge and awareness through proper training of these guidelines and policies to be at their best in providing excellent education to children.

As Serah and Setiawati (2020) emphasized in their study, there is a need for strategic steps in establishing and regulating a policy to establish a legal service institution and teacher protection to realize equitable teacher protection.

Although policies have been established to protect the child, and teachers are very much willing to abide, the crucial problem faced by teachers is whether they must punish students who violate school rules and regulations. Despite the intention to uphold discipline, often parents and 
people see it as a violation of the Child Protection Act, so report the disciplinary actions of teachers to DepEd higher-ups and, worse, to the TV host known to litigate people in front of cameras for TV and social media.

\section{Conclusion}

This section presents the conclusions of the studies based on the results and discussion of the study. The Senate Bill 956 (Teacher Protection Act), authored by Senator Sonny Angara, was critically analyzed on this paper based on the three emerging themes evident in the provisions and mandates of this senate bill. These themes include (1) support mechanism to public school teachers and personnel, (2) enhanced protection of public-school teachers and personnel, and (3) training on guidelines and classroom discipline for public school teachers and personnel.

As to the support mechanism to public school teachers and personnel, the analysis of the law reveals that, aside from how the Magna for Public School Teachers promotes the economic welfare of the school teachers and personnel, it is also necessary that the government, specifically the Department of Education, provides a wide array of support for teachers in their professional development relating to student discipline and classroom management. Since teaching is a profession that requires the ability to be responsive to new demands and changing needs that must be provided with timely and relevant training on a variety of strategies for managing student behavior, how to counter the prevalence of teacher bullying in the workplace, handling child behavior and psychology, classroom management techniques and positive discipline.

As to the enhanced protection of public-school teachers and personnel, the analysis of the study supported that, in order to further protect the teachers in their vulnerability to becoming charged of administrative or criminal cases in a matter concerning student discipline, DepEd needs to implement and make it know to school stakeholders which acts of classroom discipline done by the teacher or school personnel will be considered child abuse or a violation of student's rights. In the creation and implementation of the guidelines, DepEd and the school must be well guided by laws that protect the rights of the students. The guideline must be well-written and communicated. This way, academic freedom on the part of the teachers and school personnel were given importance. As they perform their duties in molding the students' character, they may adapt their teaching methods and techniques in managing a classroom with disciplined students (Okilwa \& Robert, 2017).

Public school teachers and personnel being charged with administrative and legal cases must be protected by the law linked to the basic policy of the DepEd Grievance Machinery, guideline from the Civil Service Commission, Magna Carta for Public School Teachers, and other relevant laws. Confidentiality of identities of parties and proceedings was also highlighted on Senate 956 to safeguard the schoolteachers and personnel against discrimination or any adverse effect of being involved in a case. 
Finally, as to training on guidelines and classroom discipline for public school teachers and personnel, DepEd needs to implement a centralized and unified set of rules and guidelines for all divisions across the country and not just rely on each division's efforts. Some divisions have already come up with their guidelines on discipline, while others have not (Welsch \& Little, 2018). There should be uniformity in behavior/discipline management so teachers can better deal with classroom management well, and they could avoid getting charged for child abuse and deal with it somewhat and accordingly- no bias, no rank discrimination.

DepEd also needs to identify which acts or disciplinary methods/strategies are not categorized as child abuse. There is a need to revisit policies to develop to protect teachers from legal charges. Serah and Setiawati (2020) emphasized in their study that there is a need for strategic steps in the form of the importance of establishing and regulating a policy to establish a legal service institution and teacher protection to realize equitable teacher protection and not just inform and train teachers about them but maybe give them a copy of guidelines they could refer to alongside conditions or situations that are classified a not a child abuse act.

Moreover, Tertiary Education Institutions (TEI) should also update their curriculum with legal courses to better equip future teachers before they embark on the teaching profession (AlbaredaTiana et al., 2018). This way, they will have at least the basic knowledge on the Child Protection Policy Act, Magna Carta for Public School Teachers, and, if officially passed into law, the Teachers' Protection Act. If the Magna Carta can be extended to private schools, it would also empower the teachers there. It is further advised that more research should be conducted on teachers' situations/conditions to make changes in education. As researchers in education believed, if want changes in the education system, write a research about the concerned issue and have its results and recommendation known (Mansfield, Fowler, \& Rainbold, 2018).

\section{References}

Albareda-Tiana, S., Vidal-Raméntol, S., Pujol-Valls, M., \& Fernández-Morilla, M. (2018). Holistic approaches to develop sustainable competencies in pre-service teacher training. MDPI Open Access Journals, 10(10). DOI: 10.20944/preprints201809.0001.v1.

Amin, M., \& Ahmed, T. (2021). Challenges Faced by Teachers About Inculcating Islamic Values: Pilot Inquiry. International Journal of Social Learning (IJSL), 1(2), 135-146. DOI: https://doi.org/10.47134/ijsl.v1i2.11.

Anderson, K. P. (2018). Inequitable Compliance: Implementation Failure of a Statewide Student Discipline Reform. Peabody Journal of Education, 93(2), 244-263. DOI: https://doi.org/10.1080/0161956X.2018.1435052.

Baluyos, G. R., Rivera, H. L., \& Baluyos, E. L. (2019). Teachers' Job Satisfaction and Work Performance. Open Journal of Social Sciences, 7(8). DOI: 10.4236/jss.2019.78015.

Bauzon P. T. (2006). Handbook in Legal Bases of Education. National Bookstore Philippines. Bayucca, S. (2020). Teachers' Awareness and School's Responsiveness to the Child Protection Policy: Basis for a Development Plan. International Journal of Multidisciplinary Research Review, 4, 59-65. DOI: https://doi.org/10.2139/ssrn.3640895 
Bongco, R., \& Ancho, I.V. (2019). Exploring Filipino Teachers' Professional Workload.Journal of Research, Policy \& Practice of Teachers \& Teacher Education Vol.9 No. 2, December, 2019. DOI: https://doi.org/10.37134/jrppte.vo19no2.2.2019.

Bordios, E. A. (2018). Cushioning Teacher Bullying: An Exploratory Study Towards Establishing SupportMechanism. Retrieved from https://www.researchgate.net/publication/326174900_Cushioning_Teacher_Bullying_ An_Exploratory_Study_Towards_Establishing_Support_Mechanism.

Buonomo, I., Fatigante, M., \& Fiorilli, C. (2017). Teachers' burnout profile: Risk and protective factors. The Open Psychology Journal, 10(1), 190-201. DOI: 10.2174/1874350101710010190

Calderon, A.B. \& Ancho, I.V. (2018). Examining malpractice in the education context. Philippine Normal University. Journal of Research, Policy and Practice of Teacher and Teacher Education, Vo. 8, No. 2. DOI: https://doi.org/10.37134/jrpptte.vol8.no2.9.

Canter, L. (2010). Assertive discipline: Positive behavior management for today's classroom. Solution Tree Press. DepEd Order No. 40, s. 2012. Department of Education Philippines. https://www.deped.gov.ph/wp-content/uploads/2012/05/DO_s2012_40.pdf.

Cervancia, J. M., Hernandez, K. U., Rodavia, M. R., \& Roxas, E. (2019). Child Abuse and Compliance on Child Protection Policy in Private and Public Basic Educational Institutions. International Journal for Cross-Disciplinary Subjects in Education, 10(1), 3957-3963. DOI: https://doi.org/10.20533/ijcdse.2042.6364.2019.0480.

DepEd. (2020). DepEd continues to drive improvements to teaching quality with new standards for school leaders. Retrieved from Department of Education website:

https://www.deped.gov.ph/2020/10/04/deped-continues-to-drive-improvements-to-teachingquality-with-new-standards-for-school-leaders/.

Deped Tambayan .(2020). Code of Ethics for Professional Teachers Explained. Retrieved December 9, 2020, from https://depedtambayan.net/the-code-of-ethics-for-professionalteachers/.

David, C. C. , Albert, J.R.G. \& Vizmanos, J. F. V. (2019). Pressures on public school teachers and implications on quality. Philippine Institute for Development Studies. https://pidswebs.pids.gov.ph/CDN/PUBLICATIONS/pidspn1901.pdf.

Department of Education Memorandum no. 291 s. 2008 Guidelines for the Implementation of CSC Resolution No. 080096 on Working Hour For Public School teachers https://www.deped.gov.ph/2008/06/16/june-16-2008-dm-291-s-2008-guidelines-forthe-implementation-of-csc-resolution-no-080096-on-working-hours-for-public-schoolteachers/.

Department of Education Order No. 16 s 2009 Addendum to Department of Education Memorandum no. 291 s. 2008 Guidelines for the Implementation of CSC Resolution No. 080096 on Working Hour For Public School teachers.

DO 16, s. 2009 - Addendum to DepEd Memorandum No. 291, s. 2008 (Guidelines for the Implementation of CSC Resolution No. 080096 on Working Hours for Public School Teachers) | Department of Education. (n.d.). Retrieved December 15, 2020, from https://www.deped.gov.ph/2009/02/24/do-16-s-2009-addendum-to-deped-memorandum-no291-s-2008-guidelines-for-the-implementation-of-csc-resolution-no-080096-on-workinghours-for-public-school-teachers/.

Eggen, P. and Kauchak, D. (2004) Educational psychology: Windows, classrooms. Pearson Prentice Hall, Upper Saddle River. 
Estrada, J.N. (2019). Academic freedom: For the academy, not for academicians? - The Manila Times. $\quad$ Retrieved December 9, 2020, from https://www.manilatimes.net/2019/01/30/opinion/columnists/academic-freedom-for-theacademy-not-for-academicians/504162/.

García-Carmona, M., Marín, M. D., \& Aguayo, R. (2018). Burnout syndrome in secondary school teachers: A systematic review and meta-analysis. Social Psychology of Education, 22(1), 189208. DOI: $10.1007 / \mathrm{s} 11218-018-9471-9$.

Gonong, G. O. (2018). Addressing Teacher Professional Development Issues: Supporting Teacher Quality. Retrieved from Department of Education website: https://www.deped.gov.ph/wpcontent/uploads/2018/07/EducSummitAddressingTeacherProfessionalDevelopmentIssues.No v2_.pdf.

Harmsen, R., Helms-Lorenz, M., Maulana, R., \& Van Veen, K. (2018). The relationship between beginning teachers' stress causes, stress responses, teaching behaviour and attrition. Teachers and Teaching, 24(6), 626-643. doi:10.1080/13540602.2018.1465404.

Huang, F., \& Anyon, Y. (2020). The Relationship between School Disciplinary Resolutions with School Climate and Attitudes toward School. Preventing School Failure, 64(3), 212-222. DOI: https://doi.org/10.1080/1045988X.2020.1722940.

International Trade Union Confederation. (2019). Workers' and Trade Unions' Commentary on the PIDS Zero-Draft on the Philippines' Voluntary National Review on the SDGs. Retrieved from International Trade Union Confederation website: https://www.ituccsi.org/IMG/pdf/190506_workers_group_feedback_-_pnvr_on_sdgs_-_final.pdf.

Kasmawati, A. (2018). Teachers under Child Protection Act. Journal of Physics: Conference Series, 1028, 012095. DOI: https://doi.org/10.1088/1742-6596/1028/1/012095.

Korb, K.A, Musa, G. S. \& Bonat, S. B. K. (2016). The effect of training on teachers' knowledge of effective classroom management strategies in Jos Metropolis. Global Journal of Educational Research Vol 15.

Livingston, Michael Jonas Raninen, Tim Slade, Wendy Swift, et.al. (2016). Understanding trends in Australian alcohol consumption-an age-period-cohort model. Addiction, Volume 111, Issue 9, 1509-1696. DOI: https://doi.org/10.1111/add.13396 .

Magsambol, B., \& Chi, C. (2020). With a shortage of guidance counselors, how will PH students cope with pandemic? Rappler. https://www.rappler.com/nation/shortage-guidance-counselors-how-studentscope-pandemic.

Mansfield, K. C., Fowler, B., \& Rainbolt, S. (2018). The potential of restorative practices to ameliorate discipline gaps: The story of one high school's leadership team. Educational Administration Quarterly, 54(2), 303-323. DOI:10.1177/0013161x17751178

Maxwell, J. (2018). Qualitative research design: An interactive approach. Retrieved from https://www.researchgate.net/publication/320353627_Qualitative_research_design_An_inter active_approach.

Medenilla, S. P. (2018).In Union There's Strength, But What If So Few Workers Are Organized?

Business Mirror [Manila]. Retrieved from https://businessmirror.com.ph/2018/12/27/inunion-theres-strength-but-what-if-so-few-workers-are-organized/.

Mitevski, O., Popeska, B. M. \& Petrusheva, M. K., (2020). Motivation for academic work of student - future physical education teachers. New Trends and Issues Proceedings on Humanities and Social Sciences. 7(1), 200-209. DOI: 10.18844/prosoc.v\%vi\%i.4894.

Nemenzo, N. (2018). Problems Encountered by Teachers in the Teaching-Learning Process: A Basis of an Action Plan. Retrieved from 
https://www.researchgate.net/publication/324606765_Problems_Encountered_by_Teachers_i n_the_Teaching-Learning_Process_A_Basis_of_an_Action_Plan.

Okilwa, N. S., \& Robert, C. (2017). School Discipline Disparity: Converging Efforts for Better Student Outcomes. Urban Rev, 49, 239-262. Retrieved from DOI: https://doi.org/10.1007/s11256-017-0399-8.

OSWG. (2020). Gatchalian seeks Senate review on implementation of Magna Carta for public school teachers. Retrieved from https://pia.gov.ph/news/articles/1053549.

Pererva, P. G., Kosenko, A. V., Tkachev, M. M., \& Kobieliev, V. M. (2018). Innovative compliance of technology to combat corruption. Innovative Management: Theoretical, Methodical, and Application , 285-294. Retrieved from http://repository.kpi.kharkov.ua/bitstream/KhPIPress/39600/1/Pererva_Innovative_complianc e_2018.pdf.

PSA. (2019). Extent of Unionism and Collective Bargaining in Establishments: 2016 (First of a series on Industrial Relations Practices) (Vol. 21, No. 17). Retrieved from Philippine Statistics Office website: https://www.ituc-csi.org/2019-philippine-workers-and-trade.

Quismorio E.. (2020), Solon pushes holiday to recognized education support personnel. Manila Bulletin . February,2020 https://mb.com.ph/2020/02/07/solon-pushes-holiday-to-recognizeeducation-support-personnel/.

Rothstein, B. (2018). Fighting systemic corruption: The indirect strategy. Daedalus, 147(3), 35-49. DOI: 10.1162/daed_a_00501.

Sadik, F. (2018). Children and Discipline: Investigating Secondary School Students' Perception of Discipline through Metaphors. European Journal of Educational Research, 7(1), 31-45. Retrieved from https://files.eric.ed.gov/fulltext/EJ1166111.pdf.

Sahin H. \& Akinci M. (2020). Research Trends Towards Teachers' In-Service Training. Malaysian Online Journal of Educational Science. Retrieved from https://files.eric.ed.gov/fulltext/EJ126111.pdf.

Schafer N. and Barker. (2018). Responsive Classroom Management: Empowering Students and Teachers in Urban Schools. Journal of Urban Learning, Teaching and Research. Retrieved from htpps://files.eric.ed.gov/fulltextEJ1195957.pdf.

Simbre, A., \& Ancho, I. V. (2019). Examining School Climate and Teachers' Organizational Commitment. Suan Sunandha Academic and Research Review, 13(2). http://journal.ssru.ac.th/index.php/ssajournal/article/view/524/322.

Senate Bill 1189. (2019). An Act Institutionalizing Support Mechanism for Teachers and Personnel in the Public School System.

Senate, P. C. (1966). Magna Carta for Public School Teachers. Philippine Government. http://docshare01.docshare.tips/files/6716/67163834.pdf.

Shava, G.N., Heystek J. \& Chasara T. (2021). Instructional Leadership: Its Role in Sustaining School Improvement in South African Schools. International Journal of Social Learning. 1(2), 117-134. DOI: https://doi.org/10.47134/ijsl.v1i2.51.

Student Discipline and Teacher Protection Act (House Bill No. 5735) (2019). teacher. https://www.teacherph.com/student-discipline-teacher-protection-act-house-bill-no-5735/

Suharyanta, S. (2020). Implementation of legal protection for teachers to avoid criminal acts of persecution. MAGISTRA Law Review, 1(2). DOI: https://doi.org/10.35973/malrev.v1i2.1613.

Swanzen, R. (2018). Facing the generation chasm: The parenting and teaching of generations $Y$ and Z. International Journal of Child, Youth and Family Studies, 9(2), 125. DOI: $10.18357 /$ ijcyfs 92201818216 . 
Trines, S. (2017). Understanding the Causes and Social Costs of Academic Corruption. World Education News + Reviews. Retrieved from https://wenr.wes.org/2017/12/understanding-thecauses-and-social-costs-of-academic-corruption.

Tuncel, Z.., \& Cobanuglo, F. (2018). In-service Teacher Training:Problems of the Teachers as Learners. International Journal of Instruction). https://files.eric..ed.gov/fulltext/EJ1191719.pdf.

Tulfo, R. [@raffytulfoinaction]. (2019) PART 1| MOMMY, IPINA-TULFO ANG PASAWAY NA TEACHER NG KANYANG ANAK! https://www.youtube.com/watch?v=DDtsnaS78z0\&t=550s.

UNESCO (2015). The right to education and the teaching profession: overview of the measures supporting the rights, status and working conditions of the teaching profession reported on by Member States; monitoring.

Urai Musa, C., \& Ariyanti, A. (2020). SEA-teacher students' perspective: Challenges teaching English overseas in the Philippines. Borneo Educational Journal (Borju), 2(1), 14-19. DOI: 10.24903/bej.v2i1.622.

Updated DepEd Administrative Cases Rules of Procedure (2018). teacher. https://www.teacherph.com/deped-administrative-cases/.

Updated Grievance Machinery of the Department of Education (DepEd) (2018). teacher. https://www.teacherph.com/deped-grievance-machinery/.

Uz R. and Bayraktar M. (2019). Bullying toward Teachers and Classroom Management Skills: European Journal of Educational Research, 8 (2), 647-657. retrieved from https://files.eric.ed.gov/fulltext/EJ12213040.pdf.

Virtudazo, M. A., \& Guhao, E. S. (2020). Student discipline in the classroom: public school teachers' point of view. International Journal of Scientific \& Technology Research, 9(1), 271-282.

Welsh, R. O., \& Little, S. (2018). The school discipline dilemma: A comprehensive review of disparities and alternative approaches. Review of Educational Research, 88(5), 752-794. DOI: $10.3102 / 0034654318791582$.

Yuksel, Ulku .(2013). Non-participation in Anti-consumption: Consumer Reluctance to Boycott, Journal of Macromarketing Volume: 33 issue: 3, page(s): 204-216 DOI: https://doi.org/10.1177/0276146713484153. 